\title{
POTENTIAL OF AGRI-TOURISM IN VO NHAI DISTRICT, THAI NGUYEN PROVINCE
}

\author{
Nguyen Quang Thi*, Ha Van Tuyen, Nguyen Thuy Linh, \\ Duong Hong Viet, Tran Thi Mai Anh \\ $T N U$ - University of Agriculture and Forestry
}

\section{ABSTRACT}

Agri-tourism has been popular in many different countries such as Japan and Taiwan, and this tourism industry has significantly contributed to those economies. In Vietnam, this kind of tourism has recently introduced over the past decades and performed well in Mekong delta and Highlands. This study aimed to assess the potential of agri-tourism and suggest feasible solutions applying to Vo Nhai district, Thai Nguyen province. The study employed different methods to collect and analyse data such as semi-structured survey, secondary data collection and statistical comparisons. Also, this research looked at challenges and advantages from which solutions and strategy can be draw from. Agri-tourism is a new type of tourism and will be the focus of local governments in Vo Nhai district. As the district has many farming practices, natural and cultural heritages and if well-planned, the district will attract more investors and tourism business to improve the local economy.

Keywords: Agri-tourism; ecotourism; potential; Vo Nhai; Thai Nguyen

Received: 31/12/2019; Revised: 03/3/2020; Published: 17/3/2020

\section{TIỀM NĂNG DU LỊCH NÔNG NGHIỆP HUYỆN VÕ NHAI, TỈNH THÁI NGUYÊN}

\author{
Nguyễn Quang Thi*, Hà Văn Tuyển, Nguyễn Thùy Linh \\ Dương Hồng Việt, Trần Thị Mai Anh \\ Truờng Đại học Nông Lâm - ĐH Thái Nguyên
}

\section{TÓM TĂT}

Du lịch nông nghiệp đã được nhiều quốc gia như Nhật Bản, Đài Loan,...triển khai rất hiệu quả, ở Việt Nam du lịch nông nghiệp phát triển mạnh ở khu vực đồng bằng Sông Cửu Long và Tây Nguyên. Nghiên cứu này được triển khai nhằm đánh giá tiềm năng và định hướng phát triển $\mathrm{du}$ lịch nông nghiệp huyện Võ Nhai, tỉnh Thái Nguyên. Chúng tôi đã sử dụng một số phương pháp nghiên cứu chủ yếu là phương pháp điều tra số liệu, tài liệu thứ cấp, phương pháp phỏng vấn bán cẩu trúc, phương pháp điền dã, phương pháp thống kê, phân tích, so sánh tổng hợp, để đánh giá tiềm năng phát triển du lịch nông nghiệp của huyện Võ Nhai. Đồng thời nghiên cứu đã phân tích và chỉ ra những khó khăn, thuận lợi, từ đó đề xuất một số định hướng và giải pháp phát triển $\mathrm{du}$ lịch nông nghiệp huyện Võ Nhai trong thời gian tới. Du lịch nông nghiệp là lựa chọn mới, một hướng đi mới của nhiều địa phương trong thời gian tới, để áp dụng có hiệu quả phát triển ngành Du lịch nông nghiệp thì huyện Võ Nhai cần thiết phải mở rộng điều tra phân tích xây dựng đề án cụ thể về phát triển du lịch nông nghiệp, có như vậy thì việc triển khai thực hiện mới tranh thủ được sự điều tiết ngân sách của trung ương, của tỉnh Thái Nguyên, đồng thời mới thu hút được nhiều nguồn đầu tư, xã hội hóa của doanh nghiệp, sự đồng thuận và nhận thức được sâu sắc khi tham gia phát triển du lịch nông nghiệp của người trên địa bàn toàn huyện.

Từ khóa: Du lịch nông nghiệp; du lịch sinh thái; tiềm năng; Võ Nhai; Thái Nguyên

Ngày nhận bài: 31/12/2019; Ngày hoàn thiện: 03/3/2020; Ngày đăng: 17/3/2020

\footnotetext{
* Corresponding author: Email: nguyenquangthi@tuaf.edu.vn
}

DOI: https://doi.org/10.34238/tnu-jst.2020.03.2496 


\section{Introduction}

Agri-tourism, a popular model, has implemented by many countries in the world. This model brings high benefits for both Agriculture and Tourism by transforming traditional agriculture to tourism combined agriculture. In the world, this model flourished in the 80s and 90s of the 10th century. Each country has its own process of formation, development and deployment methods for agri-tourism. Japan has "Green tourism"; Taiwan's agricultural tourism has developed with an important reason of protecting the farm the agricultural ancient based on economic clusters and private tourism farms...

According to the Vietnam National Administration of Tourism, many localities, organizations and individuals have invested in agricultural tourism development over the past years. Currently, Vietnam has many agricultural tourism models such as hydroponic vegetable garden, high-tech flower growing site in Da Lat (Lam Dong); experience cashew garden in Binh Phuoc; home fruit garden in Binh Duong, grape farm Ninh Thuan; garden tours, floating markets in the Mekong Delta region... Some typical tours have become popular tourist attractions such as visiting the village model of Yen Duc (Quang Ninh), visiting Moc Chau farm (Son La), Tra Que vegetable village (Hoi An, Quang Nam), or garden tours, floating markets in the Mekong Delta region... Agricultural tourism models with direct participation of indigenous people, has created abundant, attractive tourism products, while bringing higher incomes for farmers, becoming an effective method to reduce poverty.

Although Vo Nhai district, Thai Nguyen province has many advantages, the tourism industry in general and the agricultural tourism in particular only receive a modest number of visitors each year. Tourism researches in Vo Nhai district are very few, there are no specific projects or scientific research on agricultural tourism, mainly news articles, news pages about general tourism potential.
For this reason, this study investigated the results of operating models of economic development based on agricultural tourism that have been successful in many localities throughout the country to potentially provide useful solutions or models for the future tourism development of Vo Nhai district with the integration of local cultural, indigenous and landscape characteristics.

\section{Research Method}

* Methods of surveying and secondary data collection

* Approach of semi-structured interview: Method of semi-structured interview to consult experts, managers of the Department of Culture, Sports and Tourism, Leaders of the People's Committee of Vo Nhai District, and other relevant department leaders businesses that have been deploying tourism projects in Vo Nhai district, questions focusing on advantages, challenges, orientations and solutions for tourism development. Agricultural calendar in Vo Nhai district. The total of respondents involved to semi-structured interview is 30 .

* Interview approach: The authors have conducted a survey of tourist destinations associated with agriculture in Vo Nhai district to assess the on-site situation of agricultural tourism from which practical and specific analysis and evaluation are summarised.

* Statistical analysis and approach: Based on documents and data on agricultural tourism activities in Vo Nhai district, Thai Nguyen province.

\section{Results and Discussion}

\subsection{Overview of Agricultural Tourism}

\subsubsection{Concept of agricultural tourism}

Agricultural tourism is described as visiting farms or any horticulture, farming or agribusiness in order to enjoy, learn and participate in local activities. The type of agricultural tourism has been interested in the world since the 1990s and has only recently been established in Vietnam.

When considering the benefits that tourism brings to agriculture and farmers, 
"Agricultural tourism is a type of tourism developed by the owner or the operator of a farm for the purpose of improving knowledge and leisure time for the public, promoting farm products and thereby increasing farm incomes"[1].

When a tourist activity is an interest, "Agritourism is a concept that only works to visit a farm or any facility operating in the agricultural sector for the purpose of relax, raise awareness, and be able to actively participate in activities of that farm or facility"[2].

In Vietnam, the definition of "agricultural tourism is a type of tourism that creates tourist products based on the basis of agricultural production, including production means and land, people, production processes, methods of farming techniques and products... and natural factors related to agricultural production such as climate, topography... " [3].

Thus, agri-tourism is a term that refers to farm visits or agricultural production and agribusiness processes for the purpose of awareness, interest, education or relaxation, including both agricultural resources, natural resources, and cultures. Agri-tourism helps to effectively exploit the abundant local agritourism advantage, creating additional sources of income for farmers, stimulating the diversity of economic and business activities in rural areas [4].

\subsubsection{Character of agricultural tourism}

Agri-tourism is a new, exciting and rewarding tourism market segment, a diverse combination of relaxation, study and experience. Therefore, the agri-tourism has the following characteristics:

- Agri-tourism creates tourism products for tourists mainly based on agricultural production. Therefore, resources of this type of tourism are all that serve agricultural activities.

- Space for organizing agricultural activities for tourists is farms, fields, gardens, planted forests, ponds, domesticated plants and animals.

- Participants in the organization of agricultural tourism may be the head of the household, garden house, forest owner, farm owner, owner, agricultural cooperative, owner of agricultural enterprise, etc.
- Agri-tourism can be seen as a way to export agricultural products and to make a thorough marketing of product origin records, especially when the need to protect the health of the social community against risks Environmental pollution in big cities is increasing.

- Agri-tourism focuses on studying and experiencing agricultural activities, enjoying the beauty of the natural/human landscape through farming practices.

- Agri-tourism will have a less negative impact on resources if it promotes environmental awareness and contributes to preserving traditional values by selling agricultural products and traditional handicrafts. The profits from tourism activities are to preserve and promote the indigenous culture.

- Tourism industry has abundant labor force, tourist guides directly participate in service activities for tourists mainly locals - they are born and raised on agricultural land. Therefore, farmers should be very knowledgeable about agricultural life, methods and techniques of farming and have much experience in agricultural production. Therefore, the local people will guide visitors to participate in agricultural activities enthusiastically, thoughtfully and bring visitors a lot of useful knowledge.

- Tourism is low cost due to the simple and easy to use physical equipment to satisfy the tourist needs, thus attracting many tourists to visit.

\subsubsection{Role of agricultural tourism}

The advantages of this type of tourism, it can be seen that this is a type of tourism that is fully capable of meeting the requirements set for sustainable tourism development in Vietnam. This is reflected in the positive effects that this type of tourism brings in many aspects such as:

- Increase income for local communities through the consumption of products and services by tourists traveling to rural areas where poverty is still high. This is the economic benefit - a factor that contributes to improving and improving the quality of life for local communities, thereby contributing positively to reducing the negative impacts of local communities on landscape values of 
natural environment, thereby contributing to the conservation of natural resources and the environment, ensuring conditions for the sustainable development of tourism.

- Help the local community to benefit from the completion and development of tourism infrastructure (transportation, electricity, water, post and telecommunications, etc.), especially those who do not have direct conditions. Participate in travel services. This contributes to ensuring fairness in tourism development, one of the important contents of sustainable tourism development

- Creating jobs and solving unemployment problems in rural areas, especially for women and young people as well as in leisure time, leading to changes in labor structure and labor skills in the area. Through tourism, local people will directly participate in the production process and meet the needs of goods and services for tourists, thereby this can reduce the number of people from rural to urban areas. The town seeks employment to make a living, contributing to social stability, ensuring the sustainable development, including tourism.

- Restore and promote traditional cultural values such as architectural works, craft villages, festivals, customs and practices in agricultural life, traditional dishes and local products,... This has contributed greatly to the sustainable tourism development from the perspective of resources and tourism environment.

- Improve the intellectual of the local community, develop vibrant rural areas, narrow the development gap between urban and rural areas.

- Promote cultural and economic exchanges between regions, countries and ethnic groups around the world. This is an important factor in preserving and promoting the traditional cultural values of the nation, while creating opportunities for rural economic development in the direction of modernization, ensuring sustainable development in general. and sustainable tourism development in particular. In addition, participating in agricultural tourism activities is a positive direction contributing to improving the understanding of socio-cultural, landscape, craft villages, educating labor awareness, environmental awareness for everybody.

3.2. Potential of agricultural tourism in Vo Nhai district

\subsubsection{Geography}

Vo Nhai is a highland district of Thai Nguyen province, a particularly difficult area located in the Northeast of the province, along Highway $1 \mathrm{~B}$ adjacent to two high mountain ranges, with geographical coordinates 21036' to 21056' latitude North and 105045' to 106017' East longitude.

-The North borders Na Ri district (Bac Kan). -The East borders Bac Son district (Lang Son). -The South borders on Yen The district (Bac Giang).

-The West and Southwest borders Dong Hy district (Thai Nguyen).

Vo Nhai has a great position for trading and developing agri-tourism in Nguyen province with Bac Kan, Lang Son and Bac Giang provinces.

The total natural area according to the administrative boundaries covers an area of $83,942.57$ ha, consisting of 15 administrative units: 1 town and 14 communes, with 172 hamlets and villages.

\subsubsection{Natural potential}

\subsubsection{Landscape characteristics}

The outstanding feature of Vo Nhai district's terrain is high mountains, and Ngan Son mountain range runs from $\mathrm{Bac}$ Kan to the northeast - southwest while Bac Son mountain range runs from the northwest southeast, so the district has a complex terrain, hills and mountains which are suitable for traditional and ethnic farming practices.

Slopes and limestone mountains account for $92 \%$ of the area, the flat areas favorable for agricultural production account for a small proportion, focusing mainly on stream furrows, along river banks and valleys of limestone mountains.

The average height above sea level is from $100-800 \mathrm{~m}$, agricultural land is distributed at an altitude of $100-450 \mathrm{~m}$. The district is divided into 3 sub-regions as follows:

- Sub-region 1: Including communes and towns along Highway $1 \mathrm{~B}$, that is Dinh $\mathrm{Ca}$ 
Town; La Hien, Lau Thuong and Phu Thuong communes, with a total area of $14,046.46$ ha (accounting for $16.72 \%$ of the district's total natural area); This is a high concentration of population with a population density of 154.69 people $/ \mathrm{km}^{2}$. Characteristics of this region have transport and irrigation systems that are favorable for the development of Industry - Small industry - Services and agricultural production, tourism - ecology.

- Sub-region 2: Including 5 southern communes: Trang Xa, Lien Minh, Phuong Giao, Dan Tien and Binh Long with a total area of 26,177.44 ha (accounting for 31.16\% of the total natural area of the district). The population density is 106.31 people $/ \mathrm{km}^{2}$. The topography is hilly, divided by many crevices, streams, rivers, and alternating with limestone mountains with flat sandbanks suitable for the development of short-term and long-term industrial crops, maize, soybean and combination. fruit trees, forestry trees and cattle development.

- Sub-region 3: Including Nghinh Tuong, Sang Moc, Thuong Nung, Vu Chan, Than Sa and Cuc Duong communes with a total area of $43,786.54$ (accounting for $52.12 \%$ of the district's natural area); The population density is relatively low at 34.11 people per $\mathrm{km}^{2}$. The characteristics of this region are large land, hills and streams, which are very convenient for raising cattle and developing forestry and ecotourism.

It is noted that the terrain and geomorphology of the district are not flat, the division is strong, the land is formed mainly of red and yellow soil in the mountains and ancient alluvial soil, as a result, it is not favorable for the development of agricultural production. Industrial crops, especially wet rice, are difficult to develop transport and irrigation infrastructure and goods exchange within and outside the district.

\subsubsection{Climate}

The climate has a common feature of the Northern mountainous climate divided into two distinct seasons: the rainy season and the dry season.

\section{- Temperature:}

Located in cold areas of Thai Nguyen province. The Northeast is the coldest region of the province, the Southwest is at average level.

The average temperature is above $22.4{ }^{\circ} \mathrm{C}$ (the highest temperature of the year is June, July, August, the hottest 8 months is July with average temperature of $27.8{ }^{\circ} \mathrm{C}$; The lowest month is January, middle average of $14.9{ }^{\circ} \mathrm{C}$; The winter months from November to January of the following year have an average temperature lower than the annual average temperature), the average number of sunny hours is 1,500 - 1,800 hours/year.

\section{- Rainfall:}

Rainfall lasts from April to October, dry season from November to March next year. Average annual rainfall: $1,941.5 \mathrm{~mm}$, lower than other regions of Thai Nguyen province $(2,050-2,500 \mathrm{~mm})$ and unevenly distributed, concentrated rainfall is concentrated in the rainy season months with $1,765 \mathrm{~mm}$, accounting for $91 \%$ of the annual rainfall. The month with the highest rainfall is August every year $(372.2 \mathrm{~mm})$. Heavy and concentrated rains cause soil erosion, floods affect crops, soil fertility and construction works.

\section{- Moisture:}

The annual average humidity in the district ranges from 80 to $87 \%$; In the dry season, especially in the last months of the year (November and December), low humidity causes difficulties for late winter crop development, but also facilitates the harvest and preservation of agricultural products during this period.

\section{- Annual evaporation:}

The annual evaporation volume in the district is about $985 \mathrm{~mm}$, in January the largest evaporation is up to $100 \mathrm{~mm}$. In the dry season, the amount of evaporation is much greater than the rainfall, the humidity index $<0.5$ should lead to severe drought, without proper watering and humidification, it will greatly affect the growth. and productivity of crops.

\subsubsection{Hydrology}

Vo Nhai is a mountainous district, the terrain is highly divided by rocky mountains and soil mountains, so the water source is plentiful, 
but unevenly distributed in the sub-regions of the district. In addition to surface water from rivers and streams, there are other water sources from caves in the limestone mountains that have been used for production and daily life.

The district has two tributary systems belonging to the $\mathrm{Cau}$ and Thuong river systems, distributed in the southern and northern regions, providing most of the irrigation water for agricultural land areas of the two regions.

Nghinh Tuong River: is the largest river running through the North of the district, is a tributary of Cau River, originating from the arc of Bac Son (Lang Son), running through Nghinh Tuong, Sang Moc, Thuong Nung and Than Sa communes. into the Cau River.

Rong River: is run in the south of the district, it is a tributary of the Thuong River originating in Phu Thuong commune, running through the towns of Dinh Ca, Trang Xa, Dan Tien and Binh Long and flowing into Bac Giang province.

\subsubsection{Forest resources}

Vo Nhai is a highland district with tropical climate, so the forest vegetation is very rich and diverse, the forest tree group has many different levels, in limestone mountains and soil mountains. Including anise, pine, acacia, eucalyptus, bamboo, shrub ... in which star anise, pine, eucalyptus are high economic value trees being developed in the district. However, on the forest land, the proportion of valuable timber trees is very small, currently there are mainly trees of group 4 and group 6 . The area of production forest land is 28,538.57 ha; protection forest area has $17,033.70$ ha, land with special use forest is $16,186.70$ ha.

\subsubsection{Cultural potentials}

\subsubsection{Ethnic community and cultural heritages}

The district is a mountainous district located in the Northeast of Thai Nguyen province, Vo Nhai is home to many ethnic groups. In particular, the Tay and Nung occupies $21 \%$, the Kinh accounts for $38 \%$, and other ethnic minorities $41 \%$. This is a great advantage for Vo Nhai to develop Agri-tourism associated with the cultural of ethnic minorities in Viet Bac historical relic sites. Some cultural and intangible sites in Vo Nhai district are presented in Table 1.

Table 1. Some cultural and intangible sites in Vo Nhai district

\begin{tabular}{cccc}
\hline STT & $\begin{array}{c}\text { Intangible Cultures } \\
\text { (Local and ethnic singing) }\end{array}$ & STT & $\begin{array}{c}\text { Intangible Cultures } \\
\text { (Local and ethnic singing) }\end{array}$ \\
\hline 1 & -"Then" singing & 4 & -"Pao Dung" singing \\
2 & -"Soong Co" singing & 5 & -"Sly" singing \\
3 & -"Tac Xinh - Sinh Ca" dancing & & \\
\hline
\end{tabular}

(Source: Vo Nhai Dept. of Culture and Information)

These dances and singing songs of Vo Nhai ethnic minorities are often performed in festivals, festivals, community events, weddings, and social gatherings.

\subsubsection{Landscape, historic and cultural sites}

Cultural and landscape heritages recognized at national and provincial level in Vo Nhai district are depicted in table 2 .

Table 2. Statistics of cultural and landscape heritages recognized at national and provincial level in Vo Nhai district

\begin{tabular}{llc}
\hline No & \multicolumn{1}{c}{ Heriatge } & Locations/ communes \\
\hline 1. & Ancient Stone Age Archaeological Relic Site in Than Sa (Stone Roof Roof) & Than Sa \\
2. & $\begin{array}{l}\text { Historical site The location of the Second Army Corps was established on } \\
\text { Trang Xa }\end{array}$ & \\
3. & September 15, 1941 (Khuon Manh site) & Phu Thuong \\
4. & Hang Sa Khao landscape site & Phu Thuong \\
5. & Huyen cave & Trang Xa \\
6. & The relic where President Ho Chi Minh lived and worked in October 1947 & Lien Minh \\
& in Vang hamlet &
\end{tabular}




\begin{tabular}{llc}
\hline No & Heriatge & Locations/ communes \\
\hline 7. & Seven-story waterfall & Than Sa \\
8. & Rain Waterfall & Than Sa \\
9. & Place for setting up Vo Nhai district Party Committee & Phu Thuong \\
10. & Place of President Ho Chi Minh visiting the Party & Dan Tien \\
11. & Place of establishing Vo Nhai revolutionary government & La Hien \\
\hline
\end{tabular}

(Source: Thai Nguyen Dept. of Sport and Tourism)

In Vo Nhai district, there are 11 cultural and landscape heritage recognized at the national and provincial levels, they are located in the communes of Than Sa, Trang Xa, Phu Thuong, Lien Minh, Dan Tien, and La Hien.

Unranked cultural and landscape heritages managed by communes/town of Vo Nhai district are presented in table 3 .

Table 3. Statistics of unranked cultural and landscape heritages managed by communes/town of Vo Nhai district

\begin{tabular}{llcl}
\hline No & Communes/ wards & Numbers & \multicolumn{1}{c}{ Locations/ villages } \\
\hline 1. & Cuc Duong & 2 & Truong Son \\
2. & Vu Chan & 2 & Na Ca \\
3. & Thuong Nung & 3 & Trung Thanh, Tan Thanh \\
4. & Sang Moc & 3 & Nghinh Tac, Ban Chuong \\
5. & Than Sa & 2 & Xuyen Son, Kim Son \\
6. & Binh Long & 5 & Lan Vang, Na Min, Van, Dien \\
7. & Phuong Giao & 6 & Phu Tri, Xuat Tac, Phuong Giao \\
8. & Dan Tien & 10 & Đong Quan, Đoan Ket, Thinh Khanh, Đong Chuoi, Che, \\
& & & Huong Ba \\
9. & Trang Xa & 10 & Đong Mo, Cau Nho, Đong Gianh, Đong En, Na Đong, Na Bo, \\
& & 2 & Thanh Tian, Na Đong, Nhan \\
10. & Lien Minh & 1 & Cay Boc My, Nat \\
11. & La Hien & 13 & La Hoa, La Duong, Lang Hang, La Ma, Lan Han, Lan Vau, \\
12. & Lau Thuong & & Cay Hong \\
13. & Phu Thuong & 9 & Mo Ga, Na Phai, Phuong Hoang, Na Khao, Cao Lam, Cao \\
& & & Bien, Buddha village \\
14. & Đinh Ca & 5 & Đinh Ca, Luong, Tien Phong, Truong Son, Co Rong \\
\hline
\end{tabular}

(Source: Vo Nhai Dept. of Culture and Information)

\subsubsection{Some Vo Nhai tour information}

Some tours in Vo Nhai district are depicted in table 4.

Table 4. Some tours in Vo Nhai district

\begin{aligned} & \hline No \multicolumn{1}{c}{ Tours } \\ & \hline 1 $\begin{array}{l}\text { Than Sa - Thuong Nung (Tham Giao cave, Thuong Nung pagoda, Dom waterfall) - Sang Moc (Tham } \\ \text { Luong cave, Nghinh Tac pagoda, Po Đon) }\end{array} \\ &$\hline 2 Phuong Hoang cave, Mo Ga stream (Phu Thuong), Hu cave (Bac Son, Lang Son) \\ & \hline 3 $\begin{array}{l}\text { Phu Thuong - Trang Xa (Khuon Manh forest, Huyen cave) - Dan Tien (Quan Che lake) - Binh Long } \\ \text { (snails cave) }\end{array} \\ &$\hline\end{aligned}

(Source: Vo Nhai Dept. of Culture and Information)

\subsubsection{Demands for agriculture tourism of Vo Nhai district}

- Vo Nhai district's agriculture is currently playing a key role in the district's economic development, contributing to poverty reduction, job creation, and people's income increase. Agriculture is gradually shifting towards improving production efficiency, product quality and sustainable development, the district's agro-forestry-fishery production value reaches more than 680 billion VND/year. 
- In order to serve the goal of tourism development in association with agriculture, Vo Nhai district expects to plant 500 ha and improve 100 ha of fruit trees by the end of 2020 , of which the area of fruit trees with high economic value accounts for over $80 \%$ of the area of fruit trees of the whole district, the production value of fruit trees is from 240-250 million VND/ha.

- Particularly develop a mechanism to support and encourage people to focus on planting new fruits mainly on some kinds of fruit trees such as longan, grapefruit Dien, orange orange, yellow tangerine, na dai ... focusing mainly in the communes: Phu Thuong, La Hien, Lau Thuong and Dan Tien; longan production areas in the communes: Phu Thuong, La Hien, Lau Thuong and Trang Xa; Dien grapefruit intensive farming area in communes: Phu Thuong; La Hien; Trang Xa; Phương Giao.

- In addition, the district also encourages people to develop more guava and tangerine trees in some communes with suitable soil conditions to enrich and diversify fruit trees. In the immediate future, the district has built a specific project with a total capital of over 8.6 billion dong, of which the budget is over 5.3 billion dong to support 60 percent of the price of fruit trees and 40 percent of the fertilizer price. In the first year, renovating fruit gardens, training and building VietGap model... for households participating in fruit tree development projects serving tourism development of the district.

- Supporting investment in developing fruit brand of Vo Nhai, creating conditions for organizations and individuals to build and develop brands and trademarks of their products, strengthen links with other enterprises and companies to find markets for fruit products in the district.

- Vo Nhai is a district with favorable natural conditions in fruit tree development, stable rainfall, abundant water sources including surface and groundwater sources, large land areas, especially land. hills, beaches, gray soil, accounting for $76.08 \%$ of the natural land area, red soil accounting for $4.49 \%$ of the land area, and fruit trees can be planted if advanced farming methods are applied together with other New fruit tree varieties, yield, high quality.

3.3. Advantages, difficulties and suggestions for developing agricultural tourism in Vo Nhai district

\subsubsection{Advantages}

- In recent years, Vo Nhai tourism in general and agricultural tourism in particular have been interested in investing and developing certain steps.

- The geographical location and natural conditions as above, Vo Nhai district has many advantages in traveling, economic and cultural exchanges, developing tourism, agriculture, handicraft, translation. service.

- The relatively clean ecological environment is favorable for protecting and preserving people's health.

- The security and political situation is guaranteed.

- Infrastructure for tourism development, agricultural production and other activities is focused on investment and key investment.

- The attention and leadership of the District Standing Committee, People's Council, District People's Committee leaders, Department of Culture, Sports and Tourism, Department of Information and Communications of Thai Nguyen Province, close coordination, promptly of district agencies, boards, branches and unions.

- The contingent of cultural and social officials in communes and townships has been gradually standardized in terms of professional knowledge and skills.

\subsubsection{Challenges}

- Terrain is strongly divided, fragmented land has a large impact on large-scale agricultural production.

- The climate and hydrology are divided according to seasons, causing water shortage in the dry season, flooding in the rainy season, significantly affecting the production, life and tourism activities in the locality.

- The rainfall is unevenly distributed, the rainy season has a heavy rainfall accounting for $91.6 \%$ of the annual rainfall causing inundation, leading to the phenomenon of washing away and soil erosion. 
- The land is mostly hilly, poor in nutrition, with a large slope, so it is easily degraded due to being washed away and eroding, affecting agricultural production and constructions... The narrow, average area of agricultural land per capita is also low, making it difficult for the district to exploit its potential and strengths. Advantage and disadvantage of the agri-tourism development in Vo Nhai are presented in table 5 .

Table 5. Advantage and disadvantage of the agri-tourism development in Vo Nhai

\begin{tabular}{|c|c|c|c|}
\hline N0. & Content & Response(s) & $\begin{array}{c}\text { Proportion } \\
(\%)\end{array}$ \\
\hline \multicolumn{4}{|c|}{ Advantage } \\
\hline 1 & $\begin{array}{l}\text { Agri-tourism is an effective model in many countries and localities of } \\
\text { Vietnam }\end{array}$ & 25 & 83.33 \\
\hline 2 & Local authorities and businesses are interested & 28 & 93.33 \\
\hline 3 & $\begin{array}{l}\text { Geographical location and natural conditions are favorable for trade } \\
\text { and development of agricultural tourism with adjacent provinces and } \\
\text { districts }\end{array}$ & 22 & 73.33 \\
\hline 4 & Fresh environment & 24 & 80.00 \\
\hline 5 & Safety & 24 & 80.00 \\
\hline \multicolumn{4}{|c|}{ Disadvantage } \\
\hline 6 & $\begin{array}{l}\text { The terrain is strongly divided, making challenges for large-scale } \\
\text { agricultural production }\end{array}$ & 25 & 83.33 \\
\hline 7 & Floods, flash floods, strong erosion during the rainy season & 22 & 73.33 \\
\hline 8 & travel products are simple and have not be distinct yet & 29 & 96.67 \\
\hline 9 & Some tourism spots have not explored and managed effectively yet & 21 & 70.00 \\
\hline 10 & Roads to tourist sites are not good & 26 & 86.67 \\
\hline 11 & Mobilization of socialized capital and fund is small & 25 & 83.33 \\
\hline 12 & Farmers' education levels and kills in the field of tourism are still low & 24 & 80.00 \\
\hline
\end{tabular}

(Source: Data from interview)

- Tourism products are too monotonous, souvenir items are few and not yet regional characteristics. So, compared to many other tourist destinations in the province, this place is not really attractive.

- There are still many agricultural tourist sites that have not been managed and exploited, so it has not generated any revenue and brought no revenue to the State budget. Many places are quite close to the national highway, as there are very few visitors because the roads are still difficult, there is no connection with other destinations, lack of accommodation, catering services.

- Investment capital sources have only occurred in historical sites and places of scenic beauty which have been recognized and ranked at national and provincial levels, but are small, fragmented and lacking of accommodation and entertainment places. play entertainment.

- Infrastructure for tourism development is inadequate and weak, so it is not possible to attract many tourists to visit, relax, and technical infrastructure for agricultural and forestry production is limited.

- The characteristics of a highland district, with a high concentration of ethnic minorities, more than $60 \%$ of trained workers, mainly self-sufficient and self-sufficient production, therefore the living standard of the people is low, billion the percentage of poor households is still over $30 \%$ and the number of near poor households is over $11 \% \ldots$

- The labor level is still low, this is a huge difficulty in producing goods associated with the market and developing agricultural tourism.

- The mobilization of socialization in the field of tourism, agriculture... is not high.

3.3.3. Proposing directions for developing agricultural tourism in Vo Nhai district

\section{* Development strategy}

- Võ Nhai should continue implementing the planning and building investment projects for tourism development; planning and investing in transport infrastructure, parking lots, public 
bus stops, embellishing district centers to create landscapes to attract tourists;

- Build local special agricultural tourism products associated with eco-agricultural areas, introduce folk songs, traditional dishes of ethnic groups;

- Connecting with districts inside and outside the province to build tours and tourist routes such as: Dong Hy - Vo Nhai - Bac Son (Lang Son); Vo Nhai - Bac Son - Lang Son; Alliance - Xuan Luong.

* Suggesting solutions

- In order to implement a long-term, sustainable socio-economic development strategy and combining tourism development with agricultural production activities, it is necessary to consider the exploitation of land use in a scientific manner on an economical basis, reasonable and highly effective; The use arrangement must meet the land use demands for socio-economic development objectives as well as serve the planning of expansion and construction of investment in tourist resorts associated with agricultural development.

- The district's culture and information sector needs to promote the state management of culture, family, physical training and sports, tourism development in association with improving agricultural production efficiency and promoting propaganda, promote tourism activities associated with agriculture in the district.

- Continue to maintain and improve the quality and promote in-depth "Original Vo Nhai Festival" every year with various forms of diversity and effectiveness.

- Maintain and implement the movement "All people unite to build cultural life, build and replicate the cultural and arts activities, fitness and sports clubs.

- Coordinate with the Department of Culture, Sports and Tourism and functional agencies to direct and perform the state management of the conservation and promotion of the value of monuments in their respective localities according to their competence. Develop plans and organize the implementation of tourism development in association with agricultural production.

- Organize the dissemination of the effectiveness of agricultural tourism development programs in the district area.

- Develop a plan to preserve, renovate and promote the value of monuments in the district;

- Compile scientific dossiers registering to rank relics in the district with the provincial and central Culture, Sports and Tourism branches.

\section{Conclusion}

Agricultural tourism is a new option, a new direction of many local governments in the coming time, there have been many successful models of organizing and operating and developing agricultural tourism. In order to effectively apply the Agri-tourism development, Vo Nhai district needs to expand the analysis to formulate a specific project on agricultural tourism development, so the implementation is to take advantage of the central government's budget, Thai Nguyen province, and at the same time attract new sources of investment, socialization of enterprises, consensus and deep awareness when participating in tourism development in the whole district.

\section{REFERENCES}

[1]. D. Hilchey, "Agritourism: Op- portunities and Challenges," Farming Alter- native, Summer, p. $1,1993$.

[2]. R. E. Lobo, G. E. Goldman, D. A. Jolly, B. D. Wallace, W. L. Schrader, and S. A. Parker, "Agritourism benefits agriculture in San Diego County," California Agriculture, 53(6), pp. 20-24, 1999.

[3]. T. L. H. Bui, "Agricultural tourism and rural tourism," Journal of Scientific Research, School of Agricultural Management and Rural Development 2, Ho Chi Minh City, no. 1, pp. 51-53, 2010.

[4]. T. S. Nguyen and P. T. Nguyen, "Potential for developing agricultural tourism in An Giang province," Science journal, Ho Chi Minh City Pedagogical University, no. 63, pp. 82-90, 2014. 